\title{
Pension systems in EMEs: implications for capital flows and financial markets
}

\author{
Ramon Moreno and Marjorie Santos ${ }^{1}$
}

\section{Introduction and summary}

Pension systems can influence capital flows by affecting saving and investment. At the same time, the growth of pension fund assets has implications for the depth of financial markets. This paper seeks to shed light on these effects, by highlighting three relevant aspects.

First, the stage in the demographic transition. Since around the mid-1960s, lower EME fertility rates have meant lower dependency ratios, which has tended to boost saving, and also a rise in the working-age population, which has tended to boost investment. The transition has worked out as predicted in some countries but not in others. In particular, in the aftermath of crises (eg Asia in the late 1990s), saving and investment have tended to fall, and current account balances to rise. Nevertheless, current account surpluses are expected to fall or turn to deficits as populations age in coming decades. In some countries, this process has already begun.

Second, pension system design. National saving could be affected by how pension benefits are financed. Recent reforms have favoured plans based on defined contribution and prefunding, moving away from defined benefit and pay-as-you-go plans. However, with a few exceptions, it is not clear that such pension system reforms have helped increase saving. This could be due to lower precautionary saving, transitional fiscal costs associated with pension reforms, problems with low or declining pension fund coverage, and high costs.

Third, pension fund asset accumulation and financial deepening. Rapid growth in pension fund assets appears to be associated with deeper financial markets in a number of EMEs. This could also influence capital flows by affecting saving and current account balances, as well as the pattern of gross capital flows.

\section{Stages in the demographic transition}

The demographic transition in EMEs over the past 40 years may be described as follows. In a first stage, which began around the mid-1960s, declining fertility rates ${ }^{2}$ resulted in an increase in the working-age population and a decline in the share of the dependent young,

\footnotetext{
Bank for International Settlements (BIS). The views expressed in this paper are those of the authors and do not necessarily reflect those of the BIS. The authors thank, without implicating, Már Gudmundsson, Philip Turner and William White for valuable comments. Contributions by Pablo García-Luna and Jimmy Shek to this paper are also gratefully acknowledged.

2 Lee (2003) Figure 2, observes that fertility rates in developing countries began to fall in the 1960s. This reflects factors that raise the opportunity costs of bearing children. Such factors include increased productivity of labour, which raises the value of time for parents, increased investment in children because of higher incomes and higher returns on education (due to longer life spans and greater demand for more skilled workers) and higher rates of urbanisation. Certain developments reduce the value of children, such as government provision of a safety net or the availability of pensions.
} 
with only a gradual increase in the share of the elderly population (Table 1 ). ${ }^{3}$ The result has been declines in overall dependency ratios (the ratio of dependent young plus elderly to the working-age population) from around the mid-1960s to the present. (Annex Graph A1). However, this stage of the demographic transition is over or will end in the next couple of decades in some EMEs. Many countries are entering a second stage in which child dependency ratios are falling more gradually or have stabilised while elderly dependency ratios are rising more steeply (three right-hand columns in Table 1). As a result, projections up to 2050 indicate that overall dependency ratios will generally tend to rise. The implications of these trends for rates of investment and saving are discussed below.

\section{Table 1}

\section{Changes in population shares ${ }^{1}$}

In percentage points

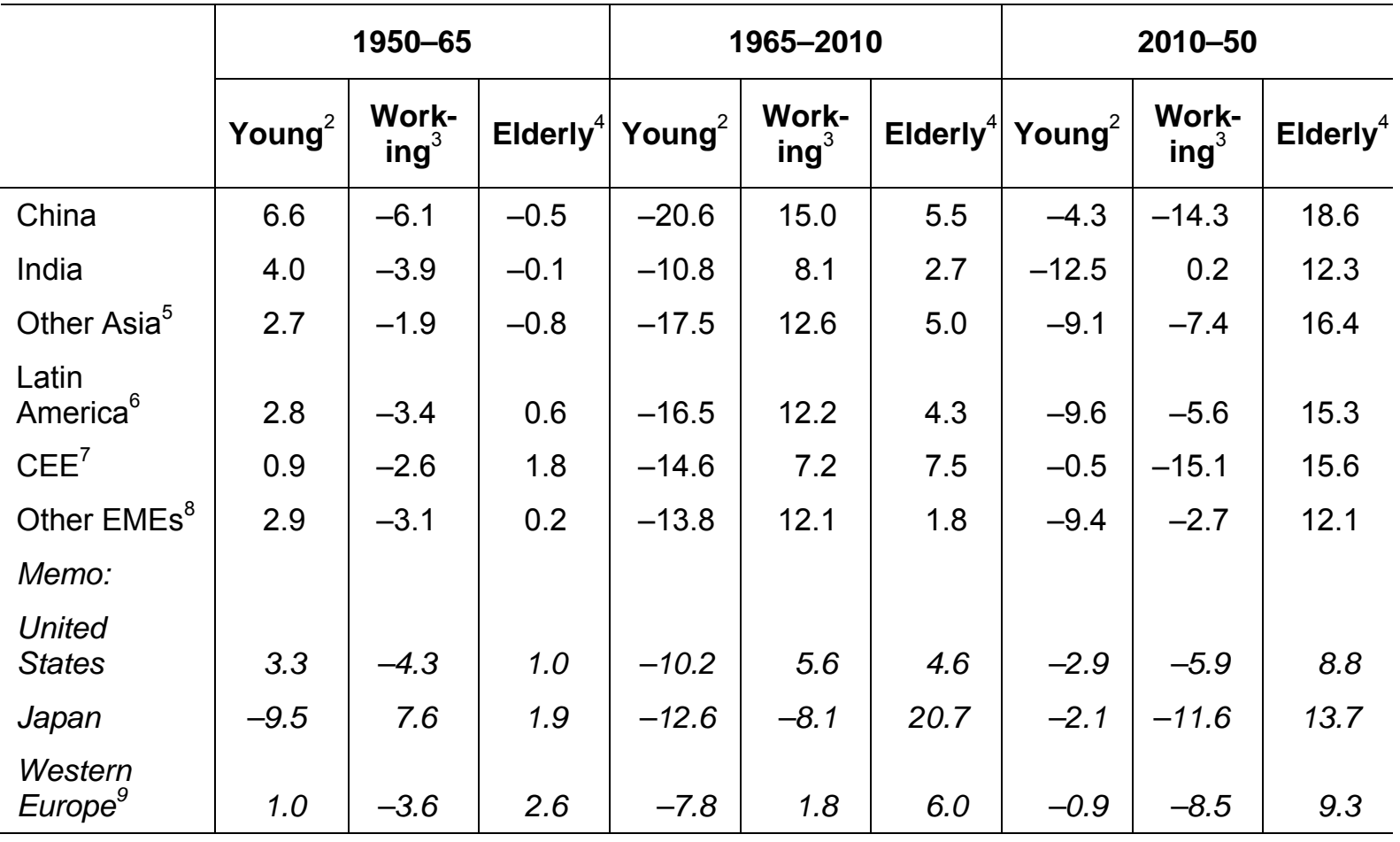

Aggregates are weighted averages based on total population data for 2000.

1 Population in each age group as a share of total population. ${ }^{2}$ Population aged 14 or less. ${ }^{3}$ Population aged 15-59. 4 Population aged 60 and above. ${ }^{5}$ Hong Kong SAR, Indonesia, Malaysia, the Philippines, Singapore and Thailand. ${ }^{6}$ Argentina, Brazil, Chile, Colombia, Mexico, Peru and Venezuela. ${ }_{7}^{7}$ The Czech Republic, Hungary, Poland and Russia. ${ }^{8}$ Saudi Arabia, South Africa and Turkey. ${ }^{9}$ France, Germany, Switzerland and the United Kingdom.

Source: United Nations, World Population Prospects.

3 The population forecasts are taken from the United Nations World Population Prospects, the most widely used source for population forecasts. The forecasts assume medium fertility. 


\section{Implications for saving, investment and capital flows}

To see how the demographic transition would affect capital flows, it is worth recalling that a country's net capital flows, or net financing requirements, depend on the current account balance $C A B_{t}$, which in turn reflects the behaviour of saving $\left(\operatorname{Sav}_{t}\right)$ and investment $\left(\operatorname{Inv} v_{t}\right)$. That is ${ }^{4}$

$$
C A B_{t}=S a v_{t}-\operatorname{Inv} v_{t}
$$

The implications of demographic changes for saving and investment would depend on the stage in the demographic transition. When populations are relatively young, increases in the labour force would tend to raise the marginal product of capital, supporting higher rates of investment spending. At the same time, the falling overall dependency ratios resulting from lower fertility and child dependency would allow households to increase their rates of saving. (This is sometimes described in the literature as the first demographic dividend.) ${ }^{5}$ Conversely, when populations are relatively old, the declining labour force would tend to lower rates of investment while the increases in overall dependency associated with ageing populations would tend to lower saving.

To shed some light on these demographic effects, Table 2 summarises trends in saving and investment over the past quarter century, with more details in Annex Graph A2.

Table 2 covers the period 1981-2006, for which data on saving and investment in EMEs are more readily available. As working-age populations tended to increase during this period, investment would have been expected to rise. At the same time, declining overall dependency ratios would tend to increase saving rates. However, Table 2 gives a much more mixed impression. In line with expectations, both saving and investment in China and India increased sharply over the period as overall dependency ratios fell, while declining in Japan where (reflecting a rapidly ageing population) dependency ratios have risen for some time now. However, contrary to expectations, increases in saving in the remaining EMEs have generally been modest, and investment ratios have generally declined. One reason is the effect of crises which appear to have persistent effects in dampening national saving and investment. In particular, the Asian crisis of 1997-98 obscures the very large increases in investment and saving that occurred in the region until 1996 (see footnote 3 in Table 2). Indeed, Bloom and Williamson (1998) find that increases in investment and saving rates (with the former exceeding the latter) were apparent in East Asia up to the first half of the 1990s as overall dependency ratios fell (Annex Graph A2). They conclude that the increase in working-age relative to dependent population contributed to East Asia's so-called economic miracle. The effects of earlier crises also appear to have dampened saving and investment growth in Latin America. In the case of the United States, the sharp decline in saving appears in part to reflect perceived increases in wealth associated with rising asset prices, and the emergence of a financing technology (home equity financing) that increased the liquidity of the wealth held by households.

4 In this paper, current account and investment data are used to estimate national saving.

5 The ultimate effects on national saving would depend on a variety of other factors. For example, the growth in output associated with higher investment and embedded total factor productivity growth could further increase household saving, corporate and government saving. However, household saving would tend to fall at higher levels of wealth. In line with this, empirical studies find that growth is associated with higher household saving, but higher real per capita income is associated lower household saving. (see eg Loayza et al (2000) and Bulír and Swiston (2006)). 
Table 2

Saving, investment and current account ${ }^{1}$

\begin{tabular}{|c|c|c|c|c|c|c|}
\hline & \multicolumn{3}{|c|}{ Change from $1980-2006(p c t p t)^{2}$} & \multicolumn{3}{|c|}{ Level in 2006 (per cent) } \\
\hline & Saving & Investment & $\begin{array}{l}\text { Current } \\
\text { account }\end{array}$ & Saving & Investment & $\begin{array}{l}\text { Current } \\
\text { account }\end{array}$ \\
\hline China & 19.5 & 10.1 & 9.4 & 54.1 & 44.6 & 9.4 \\
\hline India & 15.0 & 14.8 & 0.2 & 33.8 & 34.9 & -1.1 \\
\hline Other Asia $^{3}$ & 3.5 & -5.3 & 8.8 & 30.8 & 25.6 & 5.2 \\
\hline Latin America $^{4}$ & 0.9 & -4.1 & 5.0 & 21.9 & 20.1 & 1.8 \\
\hline $\mathrm{CEE}^{5}$ & 2.2 & -2.6 & 4.8 & 25.9 & 21.1 & 4.8 \\
\hline $\begin{array}{l}\text { Other EMEs }{ }^{6} \\
\text { Memo: }\end{array}$ & -11.4 & -2.5 & -9.0 & 25.8 & 21.2 & 4.7 \\
\hline United States & -7.0 & -0.7 & -6.2 & 13.9 & 20.0 & -6.2 \\
\hline Japan & -3.8 & -8.7 & 4.9 & 28.0 & 24.1 & 3.9 \\
\hline $\begin{array}{l}\text { Western } \\
\text { Europe }^{7}\end{array}$ & -1.8 & -3.8 & 2.0 & 20.3 & 19.0 & 1.3 \\
\hline \multicolumn{7}{|c|}{$\begin{array}{l}1 \text { As a percentage of GDP. }{ }^{2} \text { For CEE, change from 1992-2006. }{ }^{3} \text { Hong Kong SAR, Indonesia, Malaysia, } \\
\text { the Philippines, Singapore and Thailand. For this group, saving and investment increased by about } \\
7 \text { percentage points from 1980-96. 4 Argentina, Brazil, Chile, Colombia, Mexico, Peru and Venezuela. } \\
5 \text { The Czech Republic, Hungary, Poland and Russia. }{ }^{6} \text { Saudi Arabia, South Africa and Turkey. }{ }^{7} \text { France, } \\
\text { Germany, Switzerland and the United Kingdom. }\end{array}$} \\
\hline \multicolumn{7}{|c|}{ Source: IMF, World Economic Outlook. } \\
\hline
\end{tabular}

The ambiguity of the results in Table 2 highlights the extent to which factors other than demographics can play an important role in influencing national saving and investment.

As for current accounts, there appears to have been an extended cycle in which a number of EMEs started with current account deficits but more recently - often in the aftermath of crises - have experienced current account surpluses. ${ }^{6}$ Demographics would predict that over time, EME current account surpluses would turn to deficits again. For example, a recent study (IMF (2004)) covering 115 countries found that investment tended to exceed saving on average over the sample period. However, a rise in the share of the working-age population tended to increase the saving to GDP ratio more than it increased the investment ratio (by 0.72 and 0.31 respectively). ${ }^{7} \mathrm{~A}$ rise in the share of the elderly population tended to reduce the saving ratio more than it reduced the investment ratio (by -0.35 and -0.14 respectively). This implies that the current account balance would tend to rise with a larger share of the working-age population, and fall in response to ageing in the population. ${ }^{8}$

6 In the aftermath of the Asian crisis, these surpluses reflected declines in investment that exceeded declines in national saving. See Moreno (2007).

7 IMF (2004), Table 3.1, page 143, estimates that in a panel of 115 countries over the period 1960-2000 a rise in the share of the working-age population was associated with an increase in real GDP per capita, while a rise in the share of the elderly population was associated with a decline.

8 Additional perspective is provided by a study by Buliř and Swiston (2006), Table 2, who estimate the effects of changes in overall dependency ratios on private saving in a cross-section analysis of 44 developed and 
Looking ahead, a question of interest is to what extent ageing is already affecting saving and investment or might do so in the near future. Table 1 (three right-hand columns) indicates that particularly sharp declines in the shares of working-age population and increases in the shares of the elderly are projected for CEE and China. The declines in shares of working-age population and increases in elderly population are roughly comparable to those already observed in Japan. In CEE and China, and some other countries, the projected rise in elderly dependency is comparatively steep (Annex Graph A1).

This implies that saving and investment might be expected to fall and current accounts tend to deficit in CEE and China sooner than in other countries. However, as discussed earlier, there is considerable uncertainty about the timing of these effects because of the influence of other factors on saving and investment. For example, Singapore's population has been ageing for some time now, and elderly and overall dependency ratios are projected to rise more steeply than in other countries (Annex Graphs A1 and A2). However, while saving and investment ratios have fallen, Singapore's saving remains well above the average for EMEs, while investment ratios are somewhat above average.

\section{Graph 1}

\section{Saving, investment, current account and years to trough in dependency ratios}

In per cent
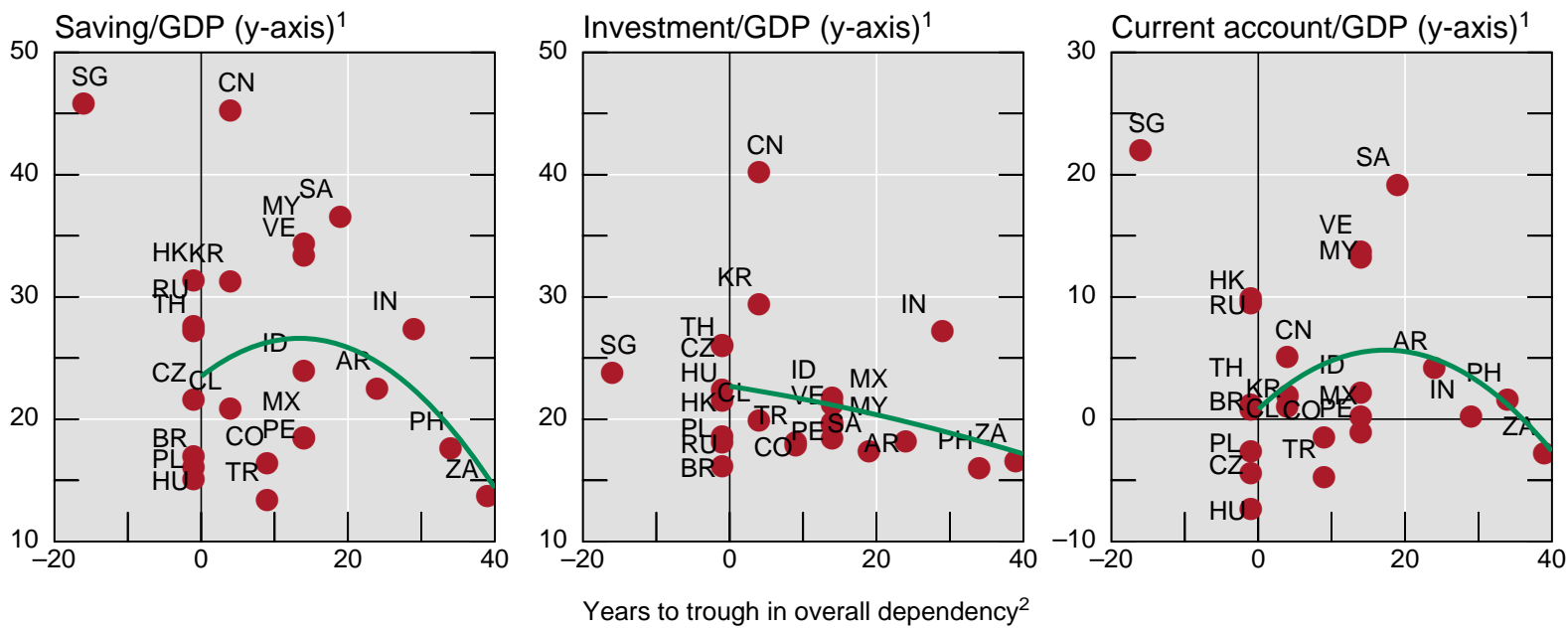

$\mathrm{AR}=$ Argentina; $\mathrm{BR}=$ Brazil; $\mathrm{CL}=$ Chile; $\mathrm{CN}=$ China; $\mathrm{CO}=$ Colombia; $\mathrm{CZ}=$ Czech Republic; $\mathrm{HK}=$ Hong Kong SAR; $\mathrm{HU}=$ Hungary; $I D$ = Indonesia; IN = India; KR = Korea; $M X=$ Mexico; $M Y$ = Malaysia; $P E=$ Peru; $P H=$ Philippines; $P L=$ Poland; $R U$ = Russia; $S A=$ Saudi Arabia; $S G=$ Singapore (not included in the regression, but the data points are shown in the graph); $T H=T$ Thailand; $\mathrm{TR}=$ Turkey; $\mathrm{VE}=$ Venezuela; $\mathrm{ZA}=$ South Africa.

${ }^{1}$ Average of 2002-06. ${ }^{2}$ Where $2006=$ year 0 . Overall dependency ratio is defined as the population less than 15 years of age plus population 60 years or older divided by the population of $15-59$ year-olds.

Sources: IMF; United Nations.

Additional perspective can be gained from Graph 1, which relates saving, investment and current account balances to the years to trough in overall dependency in a small crosssection of EMEs. In each graph, countries on the right side of the x-axis are younger, implying higher overall dependency ratios (because of high child dependency). Moving left

emerging market economies. They find that in this decade, a 1 point increase in the overall dependency ratio is associated with a 0.3 percentage point decline in the ratio of private saving to GDP. The association is higher (0.63) in industrial countries, and has risen compared to the 1990s (see also Loayza et al (2000)). Furthermore, Asian economies are found to save more than is predicted in the model, and until the end of the 1990s, Latin American countries tended to save less than predicted. These regressions explain between two thirds and three fourths of the cross-country variance of the private saving rate. 
on the $x$-axis towards zero, overall dependency ratios are low (reflecting higher working-age populations and lower child dependency ratios). Dependency ratios then rise again in response to a rising share of elderly population and lower share of working-age populations. Focusing first on saving (left-hand panel), we would expect a non-linear relationship in which saving is low in countries where the population is young (right side of the axis), tends to rise towards the middle of the graph and then declines when approaching the zero point of the $\mathrm{x}$-axis or past it. A quadratic regression line broadly reveals such a relationship in saving and in the current account. (The regression line for investment turns out to be linear.) Again, caution is needed in interpreting these results because of wide dispersion in the data. In particular, Singapore is a significant outlier with an older population and very high rates of saving. ${ }^{9}$

\section{Pension system design}

A key challenge faced by pension authorities is to generate enough resources to meet pension liabilities given a desired level of coverage and replacement income while minimising the burden on the working-age population. In this connection, there has been much discussion of how to fund pension benefits, and specifically on the extent to which countries should rely on income transfers or (alternatively) accumulated assets to finance retirement spending. National practices appear to vary considerably. Drawing on research by the National Transfers Account project, Lee and Mason (2007) estimate that reliance on assets has been comparatively high in Thailand and the United States, and comparatively low in Japan and Taiwan, China (Graph 2). ${ }^{10}$

\section{Graph $2^{11}$}

\section{Financing of old-age consumption ${ }^{1}$}

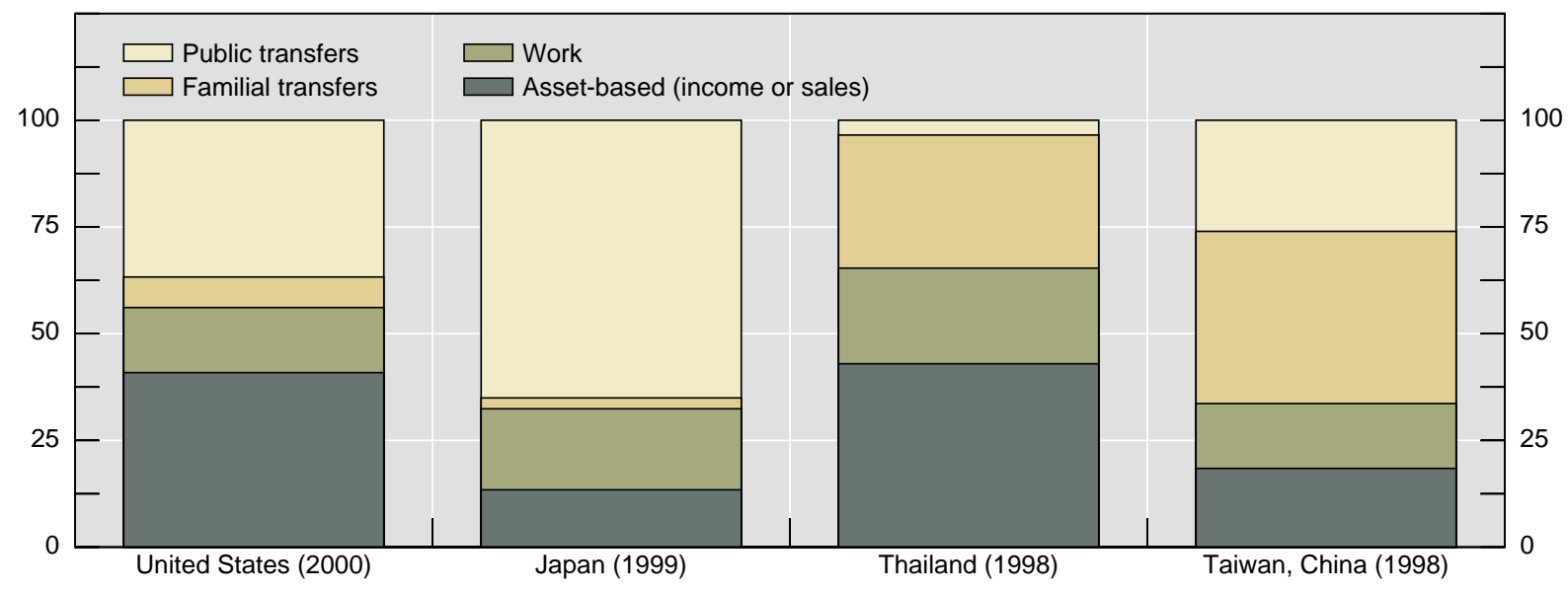

${ }^{1}$ As a percentage of total consumption.

Source: Lee and Mason (2007).

9 Singapore is such an outlier that it was not included in the regression analysis. However, all other countries shown in the graph were included in the regression.

10 At the same time, however, there appears to be significant reliance on familial transfers in Thailand and Taiwan.

11 We thank Ronald Lee for permission to use this graph. 
Some of these differences could reflect different institutional arrangements for financing old-age consumption, including differences in pension design and coverage. Traditionally. pension systems have relied on defined benefit (ie guaranteed incomes) pay-as-you-go systems, in which taxes on workers fund the pension incomes of the elderly. However, these systems tended to create very large implicit pension debts that, since they were not fully funded, raised concerns about the adequacy of replacement incomes and potential fiscal burdens. In particular, unfunded systems in which payments have to be implemented via transfers from the working-age population (eg traditional pay-as-you-go systems) raised concerns about increasing burdens on a declining pool of workers. Projected declines in the share of workers and increases in the share of elderly dependents in the population (Table 1 , three right-hand columns) imply increases in elderly and overall dependency ratios. The issue is of particular interest in countries where populations are ageing more rapidly (eg CEE, Korea and China).

The potential financing problems that can arise in more traditional pension systems are illustrated by the experience of Korea, where the pension system is a partially funded defined benefit system managed by the government. ${ }^{12}$ Holzmann et al (2004) note that reserves accumulated through the public pension system were low compared to the estimated implicit pension debt (IPD), respectively $10 \%$ and $47 \%$ of GDP, 10 years after the scheme was introduced. It was estimated that the fund would be completely exhausted within the first half of the 21 st century. ${ }^{13}$ One difficulty is that payment promises in a defined benefit plan do not depend on a pension system's performance or ability to accumulate assets. Another difficulty pertains to incentives to save under these arrangements discussed below.

Recent pension legislation (eg in Latin America) has instead sought to encourage wealth accumulation via personal saving to fund retirement consumption. In particular, there has been more emphasis on defined contribution, rather than defined benefit, which reduces the implicit pension debt. For example, Chile's pension system (introduced in 1981) is a fully funded defined contribution system of mandatory individual accounts managed by private pension fund administrators (AFPs). In the 1990s, eight emerging market economies implemented pension reforms similar to Chile's. ${ }^{14}$

In assessing the extent to which pension reforms of this latter type could reduce the burden on the working-age population, it is worth noting that in a closed economy, consumption by the old would always involve some transfer of resources away from the young. In a pay-as-you-go system, the transfer would involve the payment of taxes (eg for social security, as in the United States). In a fully funded system with private accounts (eg as in Latin America) the transfer would involve the payment of rent, interest income or dividends to, or purchases of assets from, retirees. Nevertheless, a fully funded defined contribution system can still reduce the burden on the working-age population if over time it increases saving and the stock of capital of the economy. Higher capital/labour ratios would raise worker productivity, making it easier to sustain any given level of elderly consumption out of current income. In an open economy, burdens on the working-age population could also be reduced via the accumulation of foreign assets, which can result from additional saving, or

12 However, in 2007, the National Pension Service (NPS) mandated several investment banks (Morgan Stanley, Credit Suisse) to manage part of its assets. See Song Jung-a, "S Korea turns to global banks on pensions", Financial Times, 25 July 2007.

13 The precise estimated dates vary (by 2031 according to Moon (2002) and 2047 according to the Ministry of Health and Welfare (Bateman (2007)).

14 These are Peru (1993), Argentina and Colombia (1994), Uruguay (1995), Mexico and Bolivia (1997), El Salvador (1998) and Poland (1999). In contrast, Brazil has not adopted individual accounts and recently introduced a notional defined contribution system, which links contributions to benefits, but the contributions are not placed in individually funded accounts (Matijascic and Kay (2008)). 
the diversification of pension fund portfolios (see below). This would reduce claims on domestically produced goods and services at the time of retirement (compared to the case of pay-as-you-go financing or domestic investment only).

Reformed pension systems could increase the incentive to save and reduce evasion because pension contributions are not transfers to others but are savings explicitly accruing to the individual. ${ }^{15}$ However, the impact on saving rates of pension reforms similar to those adopted in Chile does not appear to be large. ${ }^{16}$ Saving ratios in countries listed earlier as having adopted these reforms have generally not increased markedly over time (Annex Graph A2). In Poland, for example, sharp increases in saving rates pre-date the 1999 pension reforms, and national saving rates have by and large drifted downwards since the reforms were adopted. In Latin America, saving rates are still comparatively low, and increases in some cases have only offset earlier declines. ${ }^{17}$ An exception is Chile, where national saving rates have risen since the adoption of pension reforms in the 1980s.

Several factors may have limited the impact of pension reforms on national saving.

- $\quad$ Lack of financial literacy. Pension reforms will not increase saving if contributors are not aware of the possible returns from saving. Some recent survey data from Chile suggests that many pension contributors (up to around 60\%) probably lack such awareness as they cannot provide estimates of the balances on their pension accounts. It also appears that contributors with lower awareness have smaller balances (Arenas de Mesa et al (2008)).

- $\quad$ Reduced precautionary saving. Precautionary household saving outside the pension system may have been reduced to the extent to which fully funded defined contribution plans are seen as more credible than defined benefit plans that are not fully funded. This effect may be accentuated if pension funds also contribute to financial deepening (see below). The impact on overall saving would then be small and could even be negative. In a number of countries, there has also been a decline in private saving offsetting increases in government saving. Indeed, Bulír and Swiston (2006) find that the private saving offset to public saving has increased considerably in this decade; a 1 point rise in the ratio of public saving to GDP is offset by a 0.9 point decline in private saving (up from 0.4 to 0.6 in the 1990 s). This may reflect lower precautionary saving, due not only to pension reforms but also to more credible macroeconomic policies.

- $\quad$ Transitional costs. While pension reforms have increased assets to cover implicit pension debts, explicit recognition of such debts has resulted in larger fiscal deficits over a relatively extended transition period. Roldos (2007) notes that "the loss of contributions to individual accounts and the payment of recognition bonds to those who moved to the new partially or fully funded systems added in some cases more than 10 percentage points of GDP to public debt ratios". It may also be noted that in some cases, such as Peru, reforms were implemented in such a way that workers

15 Indeed, in Korea, the contributions tend to be low due to a relatively large self-employed sector, where plan participants tend to underreport their income. A less developed infrastructure for enforcement and collection also plays a role. Reforms adopted in 2007 seek to improve the sustainability of the system by gradually reducing the income replacement rate from $60 \%$ to $50 \%$ in 2008 and then to $40 \%$ by 2028 .

16 The same could be said for current accounts. In Graph 1, the largest surpluses appear to be in countries that are export-oriented (ie Singapore and Malaysia) or are commodity exporters (eg Venezuela). The extent to which mandatory contributions to provident funds might help explain the large current account surpluses in Singapore and Malaysia remains to be determined.

17 OECD (2007) reaches a similar conclusion. It also notes that empirical work on the impact of pension reforms on national saving is not conclusive. 
had an incentive to stay with the traditional pay-as-you-go system, although this was later modified (Carranza and Morón (2008)).

- $\quad$ Declining pension coverage of workers. OECD (2007, Box 2.1, pp 69-70) estimates that the weighted average of coverage for the Latin American region fell from $63 \%$ before the pension reforms to $26 \%$ in 2006 (however, the initial coverage could be an overestimate). In particular, while membership in pension funds has increased as a proportion of the registered workforce, the share of members who actually contribute has fallen in every country. ${ }^{18}$ Research is needed to uncover the reasons, but an important factor appears to be whether a pension plan is mandatory, or the default is set to automatic enrolment (Beshears et al (2008)). Given that pension plan contributions are mandatory in a number of EMEs, a large informal sector may also play a role. High administrative costs of pension systems (see next item) may also be partly responsible. ${ }^{19}$

- $\quad$ High administrative costs. Reforms that have forced workers to channel savings to fund their own retirement through private financial institutions have resulted in high fees. ${ }^{20}$ Costs in these systems average $1 \%$ to $2 \%$ in the long run, which can have the effect of lowering future pensions $20-30 \%$. Against this it has been argued that that high operating costs largely reflect marketing expenditures in retail-oriented pension fund systems and institutional reforms could reduce them (James, et al (2001)). It is also argued that government-run pension systems deliver much lower returns than private systems. ${ }^{21}$

\section{Asset accumulation and financial deepening}

\section{Pension funds: asset growth and composition}

Experience suggests that pension funds can contribute to financial sector deepening. As pension fund assets grow, they can help diversify the investor base and provide stable demand for fixed income securities as well as for new financial instruments (eg high-yield bonds, mortgage-backed securities (MBS), and foreign exchange and interest rate derivatives). The process is potentially symbiotic, as this in turn supports pension fund growth by increasing the availability of longer-maturity assets for pension fund investments.

Since 2000, pension fund assets have grown rapidly in a number of EMEs. As shown in Graph 3 , as a percentage of GDP these assets have risen by more than 8 percentage points in Chile, Colombia, Peru and Poland. (In contrast, partly reflecting their initially greater size, pension fund assets have grown only moderately in Singapore and declined in Malaysia over the same period.) However, there is still ample scope for further growth, as pension fund assets are generally still small in EMEs. In 2006, eight out of 13 EMEs shown in Graph 7 had assets of less than $20 \%$ of GDP. Among EMEs, only in Chile, Singapore and Malaysia did pension fund assets exceed $50 \%$ of GDP. Although this is comparable in size to some developed economies, it is still small compared to the $100 \%$ of GDP recorded in the United States.

18 The percentage of registered workers who contribute ranges from $11 \%$ in Peru to $31 \%$ in Mexico and $58 \%$ in Chile.

19 In line with some of these developments, the success of recent (three-pillar) pension systems in achieving their social goals is being questioned, notably in Chile (Kay and Sinha (2008)). Efforts to address this could have effects on saving and investment as well.

20 For a more severe critique, see Kotlikoff (2006).

21 See James (2004) and Roldos (2007). 


\section{Pension fund assets (as a percentage of GDP)}

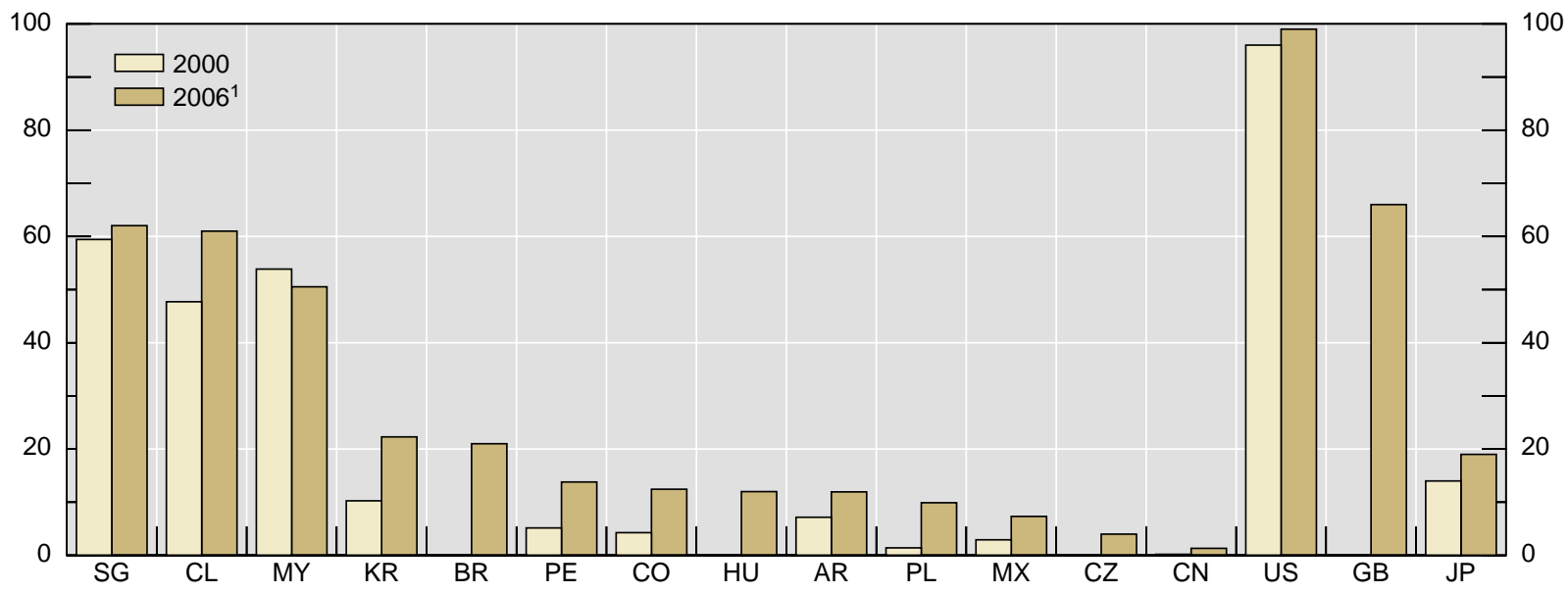

$\mathrm{AR}=$ Argentina; $\mathrm{BR}=$ Brazil; $\mathrm{CL}=$ Chile; $\mathrm{CN}=$ China; $\mathrm{CO}=$ Colombia CZ = Czech Republic; GB = United Kingdom; HU = Hungary; $\mathrm{JP}=$ Japan; KR = Korea; MX = Mexico; MY = Malaysia; PE = Peru; PL = Poland; SG = Singapore; US = United States.

${ }^{1}$ Or latest available.

Sources: OECD; Association of Pension Fund Administrators; national data.

\section{Composition of pension fund portfolios}

The impact of pension fund accumulation on the domestic financial sector depends in part on the composition of pension fund portfolios. The following aspects may be highlighted.

First, the share of assets held in financial institutions has tended to decline in a number of EMEs (see Chan et al (2006) for Latin America). This may reflect less reliance on bank deposits as investments, which could enhance demand for other financial instruments and financial deepening. However, in some countries, bank deposits remain significant. According to OECD statistics, in 2005 the share of cash and deposits in total pension fund assets in Thailand, Brazil and Indonesia was 40\%, 44\% and $71 \%$ respectively.

Second, the portfolio composition of pension fund assets in some EMEs, Latin America in particular, is highly weighted towards government bonds. Indeed, as reported by Chan et al (2006), in the majority of Latin American countries they sampled pension funds held more than half of their portfolios in government debt (in Mexico and El Salvador it was more than four fifths). Of particular interest is that in five Latin American countries (Argentina, Bolivia, El Salvador, Peru and Uruguay) pension fund assets became more concentrated in government debt between 1999 and 2005. By way of comparison, the share of pension fund assets invested in bonds (both public and private) in the United States and Japan tended to fall (between 1995 and 2005 , from $26 \%$ to $19 \%$ and from $46 \%$ to $30 \%$, respectively; see Committee on the Global Financial System (2007)).

Third, some pension funds (eg Korea or Mexico, Table 3 ) tend to allocate a relatively small amount of their portfolios to equities, even if relatively young populations (eg in India) suggest that there is scope for increasing allocation to equities. ${ }^{22}$ By way of comparison, in the United States, $41 \%$ and $24 \%$ of pension fund assets are invested in equities and mutual funds, respectively. equities in economies where populations are younger (Gollier (2005)). However, this is a contentious issue. 
Table 3

Restrictions on portfolio composition and actual asset composition

$\%$ of total assets (2006 or 2007)

\begin{tabular}{l|c|c|c|c}
\hline \multirow{2}{*}{} & \multicolumn{2}{|c|}{ Domestic equities } & \multicolumn{2}{c}{ Foreign assets } \\
\cline { 2 - 5 } & Maximum limits & $\begin{array}{c}\text { Actual } \\
\text { composition }\end{array}$ & Maximum limits & $\begin{array}{c}\text { Actual } \\
\text { composition }\end{array}$ \\
\hline India & 12 & 11 & 20 & 9 \\
Sorea & PPR & 0 & PPR & $\ldots$ \\
\hline Argentina & 50 & 13 & 20 & 10 \\
Chile & 39 & 17 & 30 & 32 \\
Colombia & 30 & 15 & 20 & 14 \\
Mexico & 15 & 0.4 & 20 & 8 \\
Peru & 35 & 42 & 10.5 & 2 \\
\hline Hungary & 50 & 8 & 30 & \\
Poland & 40 & 32 & 5 & \\
\hline Memo: & & & & \\
United States & $P P R$ & 41 & $P P R$ & \\
United Kingdom & $P P R$ & 40 & 30 & \\
Japan & 30 & & & \\
\hline
\end{tabular}

PPR = "prudent person rule".

Sources: Poirson (2007); OECD, Global Pension Statistics; OECD, Latin American Economic Outlook, 2008; Korea National Pension Service.

Fourth, with some exceptions (eg Chile), the allocation to foreign assets by EME pension funds also tends to be small.

The lack of diversification in pension fund portfolios is in a number of cases the result of restrictions on pension fund investments in equities and foreign assets (Table 3). A major reason for these restrictions is that expanding pension fund portfolios to include assets with returns exhibiting very high volatility (domestic equities and foreign assets) is believed to create an unacceptable risk of losses that could impoverish pension fund participants.

There are two arguments for liberalising restrictions on pension fund investments, both of which have to do with the gains from diversification. First, liberalisation can reduce concentration in a portfolio and consequently lower the risk of very large losses. This can be particularly important in emerging market economies which, in the past, have been vulnerable to sharp downturns or even financial crises. For example, a pension fund investing in domestic bank deposits avoids market and liquidity risk but retains counterparty risk to the domestic banking system. This risk can be reduced (at the cost of assuming some exchange rate risk) by adding foreign assets to its portfolio.

Second, liberalisation increases the set of investable instruments and potential gains from diversification. The recent performance of a variety of financial instruments suggests that these gains can be very large. For example, in this decade domestic Latin American government securities (GBI-Latin America) earned a shade over $10 \%$ annualised return 
(in US dollars) with an annualised volatility of $10 \%$ (Graph 4). However, roughly triple those returns could have been earned by investing in Latin American equities, at the cost of more than doubling volatility.

Graph 4

Returns and volatility, 2002-07

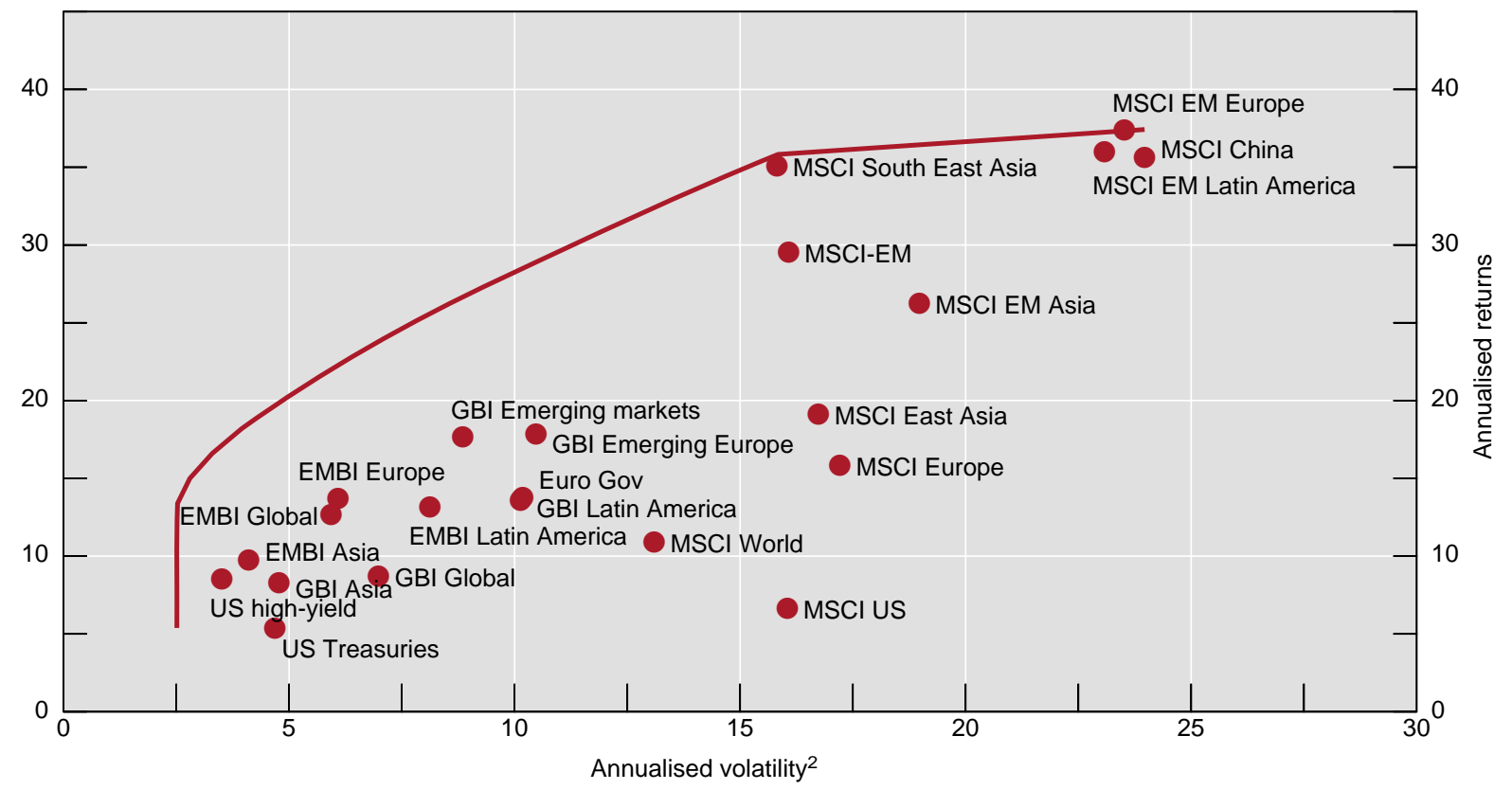

The line represents the efficient portfolio frontier. $\mathrm{EM}=$ Emerging Markets; $\mathrm{EMBI}=$ Emerging Markets Bond Index; $\mathrm{GBI}=\mathrm{Government}$ Bond Index; $\mathrm{MSCl}=$ Morgan Stanley Capital International.

${ }^{1}$ Unhedged returns in US dollars; in per cent. ${ }^{2}$ Standard deviation of returns, calculated using daily percentage changes in the return index.

Sources: JPMorgan Chase; Merrill Lynch; Datastream.

Returns can be improved not only by diversifying into equities (at home or abroad), but also by diversifying into foreign bonds. For example, adding domestic bonds from other regions to an investment portfolio could be associated with increased returns with less than proportional increases in volatility; indeed, the GBI-EM index has higher returns and lower volatility than the GBI-Latin America index. This reflects diversification benefits resulting from combining assets in a portfolio whose returns have low or negative correlations (see below).

Berstein and Chumacero (2005) provide more precise estimates of the gains from easing specific restrictions on pension fund asset allocations in Chile. Their analysis suggests that by mid-2002, in the absence of the specific pension fund restrictions applied in Chile, pension fund assets could have been higher by between $10 \%$ (for a quadratic preference or an efficient value-at-risk portfolio) and $30 \%$ (for a minimum variance portfolio) without increasing the volatility of returns (see their Figure 3 ). Put differently, for a minimum variance portfolio, with the same volatility of returns, returns to the unrestricted portfolio averaged $0.85 \%$ a month, compared to $0.67 \%$ per month for the restricted portfolio. ${ }^{23}$ This is because

23 The authors estimate the restricted portfolio by (where applicable) calibrating parameters in the objective function so as to replicate the ex post pension fund portfolio returns and volatilities. The unrestricted portfolio is selected so that in each period it is exposed to the same volatility as the restricted portfolio. The return corresponding to that volatility is then estimated. These results vary somewhat with differing assumptions about transaction costs, but the basic conclusions hold; see Berstein and Chumacero (2005), Table 3. 
the unrestricted optimal portfolio implied a larger allocation to foreign bonds and equities (about a $1 / 3$ share for the minimum variance model) than would have been the case for the restricted portfolio. Thus, for the minimum variance model, the probability of hitting the investment limit for foreign fixed income and equity instruments was estimated at about $62 \%$ and $90 \%$, respectively.

\section{How much would pension funds invest abroad?}

While steps are being taken to liberalise pension fund investments abroad in a number of EMEs, it is not clear how much pension funds will increase their investments abroad in response. On the one hand, in the case of Chile, or other EMEs, the returns from moving to an optimum share of foreign assets (and corresponding gross outflows channelled via pension funds) could be even higher than suggested by Berstein and Chumacero's (2005) estimates. In their analysis, they only consider developed country fixed and variable income instruments as alternatives to domestic assets, ${ }^{24}$ while recent experience suggests that EME pension funds could earn even higher-risk adjusted returns by investing in assets issued in other EMEs. As can be seen in Graph 4, a number of regional (EMBI, GBI and MSCI) indices dominate their developed country counterparts in terms of risk-adjusted returns. Against these advantages is the possibility that EMEs might be more vulnerable to crises, so that a pension fund that is very concerned about the risk of large losses might be less inclined to invest in EME instruments.

Much depends on the diversification benefits provided by EME instruments on average and during episodes of financial stress. As can be seen in Graph 5, equities are not fully correlated across regions over a longer period (2001-07). This highlights the opportunities for diversification benefits from EME pension fund investments in both developed market and other emerging market equities. However, an important concern is that correlations in cross-country equity returns tend to rise during episodes of financial stress. Nevertheless, EM pension funds may be in a better position to manage the risks of diversification (than, say, EM banks) because pension fund liabilities tend to be longer-term. Also, bond investments do not appear to raise such concerns, as correlations in some cases have actually fallen during episodes of financial stress.

On the other hand, diversification could be limited by a number of factors. ${ }^{25}$ Even in the absence of restrictions, there is evidence that investors prefer to invest in their own domestic markets (home bias). This is reflected in the fact that pension fund investment abroad is below the ceiling in a number of countries (Table 3). ${ }^{26}$ An important reason is that developing monitoring and management capacity to invest abroad is costly, particularly for pension funds in EMEs having little experience with investments in global financial markets. For example, as pension fund liabilities are denominated in domestic currency pension funds

24 They assume that there are four types of assets: domestic fixed, domestic variable, foreign fixed and foreign variable income (as proxied for, respectively, by promissory notes of the Central Bank of Chile of eight-year maturity, an index of all Chilean variable return instruments, an index based on all US indices, and the Dow Jones Industrial Average).

25 Limited diversification of pension portfolios has also been observed in countries with higher incomes per capita. Gudmundsson (2001) describes stages in which pension funds in Iceland first invested in domestic bonds, lending directly to members (for housing), and then increased the share of foreign assets and equity in their portfolios over a short period of time (from low single digits to 19-26\% between the mid-1990s and 2000), resulting in large increases in returns on assets. In part, this reflected liberalisation, but also awareness by pension fund managers of the need to increase returns.

26 Actual limits could also turn out to be below the ceiling because the ceiling applies to each fund individually and there are significant penalties for breaching the ceiling (eg forced sales). Under those conditions, fund managers would want to stay well below the ceiling to avoid breaches because fluctuations in market prices and mark to market accounting can push restricted asset holdings above the ceiling without any trade taking place. 
need to develop the capacity to manage currency risks; ${ }^{27}$ There is also limited availability of instruments to hedge risks, including those arising from currency or interest rate fluctuations. ${ }^{28}$

\section{Graph 5}

\section{Correlations in asset markets ${ }^{1}$}
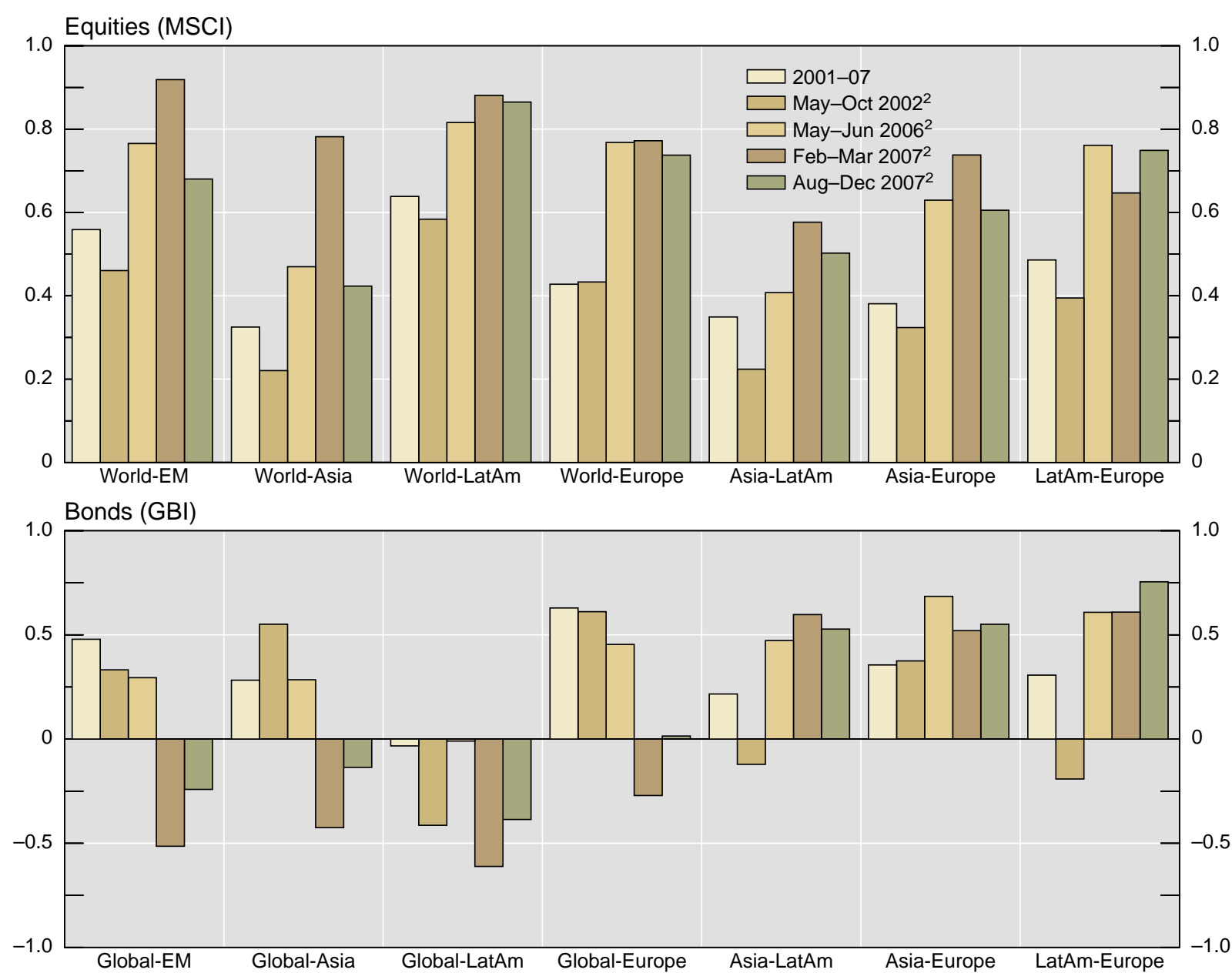

${ }^{1}$ Calculated on daily unhedged returns in US dollars. $\quad{ }^{2}$ Period of increased global market volatility.

Sources: Datastream; JPMorgan Chase.

There is growing awareness of the need to provide such hedging instruments. For example, in India market participants are now allowed to use foreign exchange forwards, swaps and options. While this is usually only against "crystallised foreign currency exposures", the range of hedging tools available is now to be expanded (Mohan (2007)). However, it is still not clear to what extent pension funds would engage in hedging even were the appropriate instruments to be made available, because hedging would be costly. An additional concern is whether pension funds could contribute to increased volatility of capital flows (Vargas and

27 With regard to monitoring investments abroad, pension funds could draw on the risk management capacity of global financial institutions by investing in vehicles such as mutual funds.

28 See Moreno (2006), Table A6 and Mohan (2007). 
Varela (2008)), which could reduce risk-adjusted returns or raise broader risk management concerns.

\section{Deeper financial markets}

As pension fund assets have grown, emerging securities markets have deepened in recent years. Domestic debt markets, which are largest in Asia, South Africa and Turkey, have generally grown in this decade. However, they have not grown in central Europe, (Graph 6 and Annex Graph A3). There has also been a tendency for stock market capitalisation to rise in EMEs in this decade, reflecting steep increases in equity prices.

\section{Graph 6}

\section{Size of financial market}
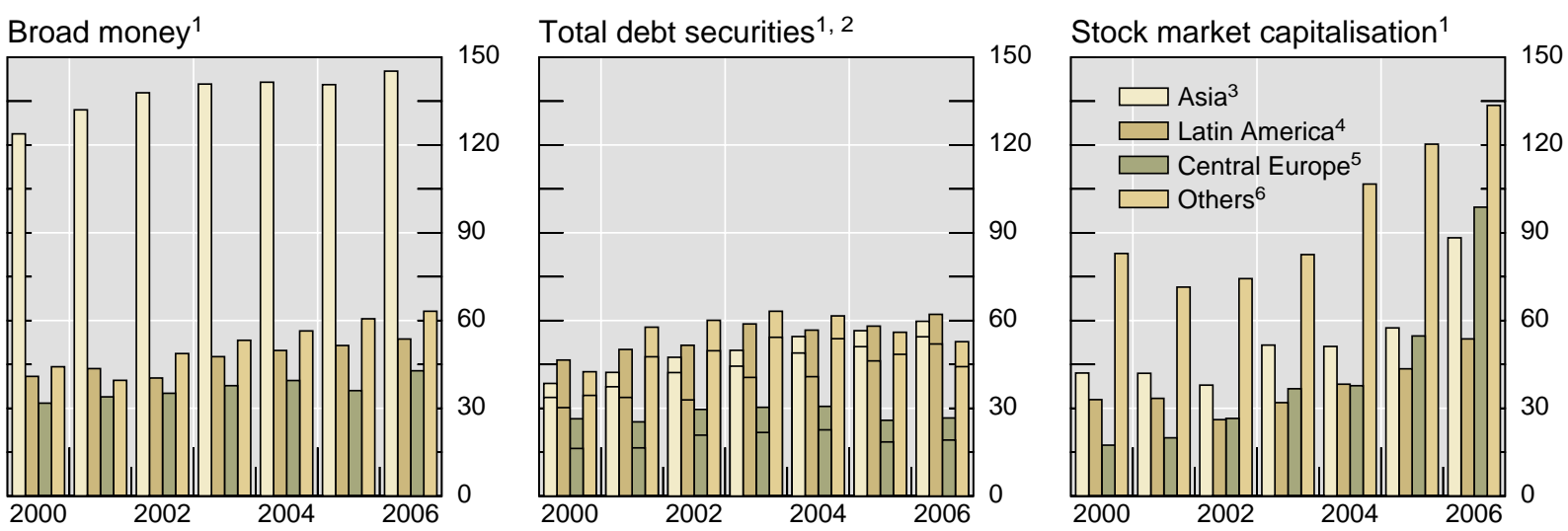

${ }^{1}$ As a percentage of GDP. ${ }^{2}$ Covers domestic (lower portion of bars) and international (upper portion of bars) debt securities. ${ }^{3}$ China, Hong Kong SAR, India, Indonesia, Korea, Malaysia, Philippines, Singapore, Taiwan (China) and Thailand. ${ }^{4}$ Argentina, Brazil, Chile, Colombia, Mexico, Peru and Venezuela. ${ }^{5}$ Czech Republic, Hungary, Poland and Russia. ${ }^{6}$ South Africa and Turkey.

Sources: IMF; Standard \& Poor's; BIS.

However, financial markets in EMEs are still not as deep as in developed countries. This is broadly reflected in (i) still low ratios of market capitalisation in securities to GDP; (ii) high ratios of bank deposits to GDP; (iii) lack of liquidity in securities markets; and (iv) low reliance on securities markets for financing.

Low ratio of securities to GDP. As illustrated in Graph 6, the ratio of debt securities to GDP ranged from less than $30 \%$ for CEE to $60 \%$ or higher in Asia and Latin America. (Annex Graph A3 provides country details.) However, this ratio was around $200 \%$ in the United States and Japan (Annex Graph A4). With the recent run-up in EME equity prices, stock market capitalisation ratios are more comparable with the $100 \%$ and $150 \%$ observed in Japan and the United States respectively, although they remain at a comparatively low $50 \%$ in Latin America.

Relatively high bank deposits. M2/GDP has recently averaged around $140 \%$ in Asian EMEs and $45-60 \%$ in other EMEs. Bank deposits are thus relatively more important in EMEs than in the US, where the M2/GDP ratio averaged $50 \%$. However, M2/GDP ratios are about as high in Japan (nearly $150 \%$ ) as they are in Asian EMEs. ${ }^{29}$

29 One implication is that in countries where pension funds hold a significant proportion of bank assets, bank interest rate liberalisation could significantly increase pension fund returns, particularly where rising inflation is a concern. Bank interest rates have been liberalised in many EMEs, although restrictions are still relevant in certain countries, like China or India. See Mohanty and Turner ((2008), Tables A4 and A5) for information on the liberalisation of bank interest rates between 1997 and 2006. In some cases, pension funds could help 
Low liquidity. The rate of turnover in financial instruments tends to be lower in EMEs than in developed markets. This can present problems for risk management (and eventual wealth accumulation), by making it difficult for investors to change their positions. As can be seen in Graph 7, debt trading volume as a percentage of GDP ranged from a low of around $10 \%$ of GDP in Asia to a high of around $150 \%$ in Latin America. By way of comparison, the corresponding ratios for Japan and the US were respectively about $500 \%$ and nearly $2000 \%$. As for equity markets, turnover tends to be lower in Latin America (around 10\% of GDP) and around $80 \%$ in Asia and "other". By way of comparison, the corresponding turnover ratios for Japan and the United States are 150\% and 280\% respectively (Annex Graph A5).

\section{Graph 7}

\section{Liquidity indicator}
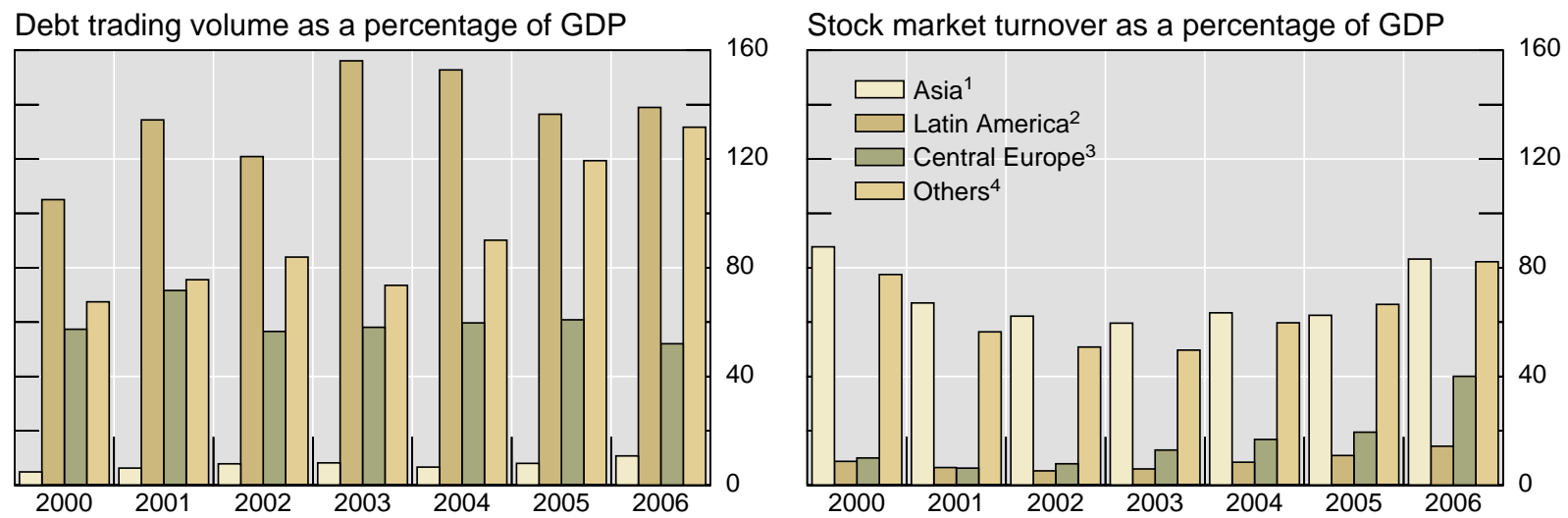

${ }^{1}$ China, India, Indonesia, Korea, Malaysia, Philippines, Taiwan (China) and Thailand. 2 Argentina, Brazil, Chile, Colombia, Mexico,

Peru and Venezuela. ${ }^{3}$ Czech Republic, Hungary, Poland and Russia. ${ }^{4}$ South Africa and Turkey.

Sources: IMF; EMTA; Standard \& Poor's.

Limited reliance on equities for financing. To illustrate, in China stock market capitalisation as a percentage of GDP is quite high (90\%), but flow of funds data indicate that between 2003 and 2005 equities accounted for only about $4 \%$ of total increases in liabilities, with bank loans and bond financing accounting for much larger shares (61\% and $35 \%$ respectively). The reasons why higher share prices do not lead to more share issuance warrant further examination.

\section{Role of pension funds in financial deepening}

The developments highlighted above suggest that further pension fund development could contribute to the deepening of financial markets. One indication is that the correlation between financial deepening and pension fund growth is comparatively strong in a number of EMEs. As shown in Table 4, stock market capitalisation is positively correlated with pension

promote interest rate liberalisation. In the case of India, pension funds could help eliminate distortions in interest rates caused by existing arrangements to support small savers (Mohan (2007)). To compensate for the lack of a social security system, the government gives small savers access to saving instruments (administered through post offices and commercial banks) that benefit from tax incentives and favourable interest rates set by the government. However, to attract deposits, banks competing with these small saving schemes tend to set rates on long-term deposits at levels higher than those which would have been obtained under competitive market conditions. This has been seen as contributing to downward stickiness of lending rates (with implications for the effectiveness of monetary policy). Improvements in the social safety net (including pensions) could address this issue. (A proposed interim solution is to benchmark these administered interest rates to market determined rates.) 
fund asset growth in Korea, Argentina, Chile, Colombia, Peru and Poland. In contrast, the correlation is negative in Malaysia and Singapore. As for domestic debt securities, the correlation is positive (in either levels or changes) in most EMEs listed.

Table 4

Correlations with pension fund assets/GDP ${ }^{1}$

\begin{tabular}{|c|c|c|c|c|c|c|}
\hline & \multirow{2}{*}{\multicolumn{2}{|c|}{ Time period }} & \multicolumn{2}{|c|}{$\begin{array}{c}\text { Stock market } \\
\text { capitalisation/GDP }\end{array}$} & \multicolumn{2}{|c|}{$\begin{array}{l}\text { Outstanding domestic } \\
\text { debt securities/GDP }\end{array}$} \\
\hline & & & Ratio & $\begin{array}{l}\text { Change in } \\
\text { ratio }\end{array}$ & Ratio & $\begin{array}{l}\text { Change in } \\
\text { ratio }\end{array}$ \\
\hline China & 2000 & 2006 & 0.27 & 0.04 & 0.81 & -0.60 \\
\hline Korea & 1990 & 2006 & 0.76 & 0.41 & 0.92 & 0.40 \\
\hline Malaysia & 2000 & 2006 & -0.38 & -0.09 & -0.28 & 0.65 \\
\hline Singapore & 2000 & 2006 & -0.20 & -0.65 & 0.82 & 0.61 \\
\hline Argentina & 1995 & 2006 & 0.48 & 0.34 & 0.94 & 0.85 \\
\hline Brazil & & & na & na & na & na \\
\hline Chile & 1982 & 2006 & 0.68 & 0.79 & 0.30 & 0.71 \\
\hline Colombia & 1995 & 2006 & 0.72 & 0.38 & 0.98 & 0.74 \\
\hline Mexico & 1998 & 2006 & 0.39 & -0.23 & 0.96 & 0.54 \\
\hline Peru & 1994 & 2006 & 0.72 & 0.44 & 0.90 & 0.20 \\
\hline Czech Republic & & & na & na & na & na \\
\hline Hungary & & & na & na & na & na \\
\hline Poland & 2000 & 2006 & 0.86 & 0.33 & 0.96 & 0.91 \\
\hline United States & 2001 & 2006 & 0.96 & 0.94 & 0.59 & 0.11 \\
\hline Japan & 2001 & 2006 & 0.98 & 0.86 & 0.64 & -0.58 \\
\hline
\end{tabular}

The results in Table 4 are broadly in line with Roldos (2007) and OECD (2007), who note that institutional investment (including by pension funds) has been associated with increases in market capitalisation of stocks and bonds. This relationship is particularly apparent in Chile. In line with this, the share of pension funds in government debt markets in a set of Latin American countries rose from 18\% in 1998 to 29\% in 2005 (Roldos (2007), Table 4). Pension fund demand is also believed to have helped stimulate the development of new financial instruments. There is also evidence of lengthening maturities in fixed income markets in Chile and Mexico, and institutional investors, including pension funds, are believed to have played an important role in this. Research also suggests that the growth of institutional investors such as pension funds can lower the cost of capital and encourage the creation of new financial instruments (Walker and Lefort (2002)). A pension fund portfolio reallocation to equities could thus boost investment and growth as well as returns for pension 
fund investors. The importance of this effect would depend in part on the extent to which firms rely on equity for their financing (which as noted earlier, can be relatively little in some EMEs). ${ }^{30}$

\section{Implications for saving and capital flows}

The implications of greater financial depth for capital flows are uncertain, but some research suggests it could affect capital flows by lowering precautionary saving and current account balances. A recent study by Chinn and Ito (2007) finds that a larger financial sector could lower current account balances under certain conditions. ${ }^{31}$ This is an issue of interest in a number of EMEs, notably China.

The effects of pension fund portfolio liberalisation on net or gross capital flows are also uncertain. However, the experience of Chile since 1998, reported by Desormeaux et al (2008) suggests that pension fund investments abroad can have a large impact on gross outflows. This impression is reinforced by evidence they cite that an increase of $10 \%$ in foreign investment limits on Chilean pension funds is associated with an accumulated depreciation of $2 \%$ of the Chilean peso against the US dollar (see Cowan et al (2008)). To illustrate orders of magnitude, at the limit of $30 \%$ that prevailed until recently, Chilean pension fund assets invested abroad would be equivalent to nearly $20 \%$ of Chilean GDP. Pending legislation contemplates significant easing of these limits which could mean large cumulative gross outflows over time in the pension fund sector. By way of comparison, foreign reserves to GDP in Latin America averaged about 10\% in 2006 (13\% in Chile) and $35 \%$ in Asia.

An issue of interest is whether outflows channelled via pension funds could help offset large gross capital inflows, thus reducing the incentives for foreign exchange market intervention and reserve accumulation in some countries. While they are not perfect substitutes for foreign reserves, pension fund accumulation of foreign assets could provide a channel for intermediating capital inflows abroad, thus providing some of the benefits that have been sought from foreign exchange market intervention and foreign reserve accumulation without the associated disadvantages. In particular, as pension fund foreign asset accumulation would be financed by domestic saving, it does not raise the issues typically associated with the financing of foreign reserve accumulation, such as the possible loss of monetary control or the carrying costs associated with sterilisation of intervention in foreign exchange markets.

30 On the other hand, some commentary suggests that the relationship between pension asset growth and market capitalisation has been weak in some countries over certain periods. Possible explanations include inadequate regulatory and financial infrastructure and a lack of a critical mass in pension fund assets under management.

31 The conditions are that the economy be less open (ie restrictions on capital flows) and the legal system be less developed (not in the top decile). 


\section{Annex I}

\section{Graph A1}

\section{Dependency ratios by country}

In per cent
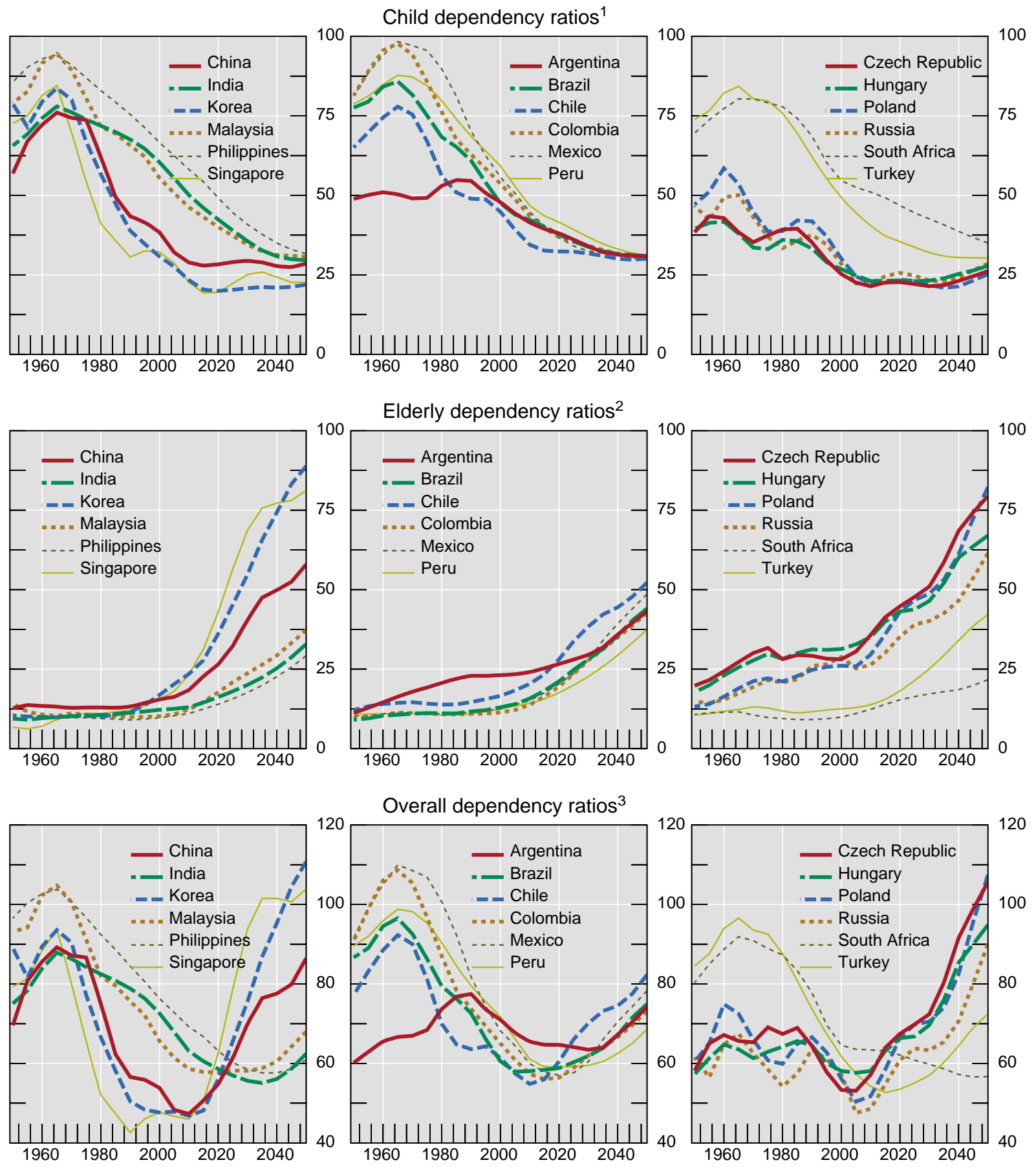

${ }^{1}$ Population less than 15 years of age / population 15-59 years old. 2 Population 60 years or older / population 15-59 years old. ${ }^{3}$ Population less than 15 years of age plus population 60 years or older / population 15-59 years old.

Source: United Nations, World Population Prospects. 
Graph A2

Saving, investment and dependency ratios

In per cent
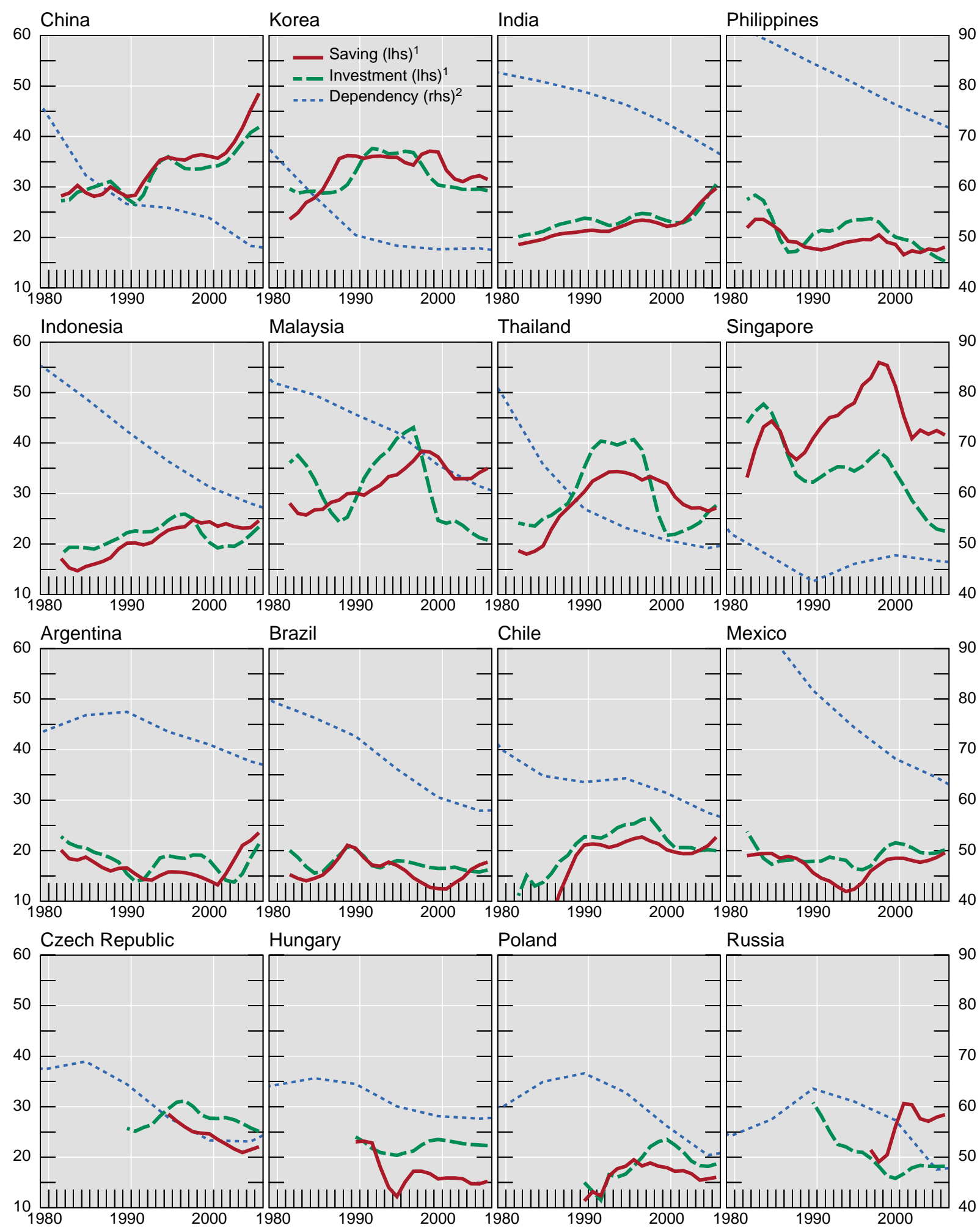

${ }^{1}$ Relative to GDP; three-year moving averages. ${ }^{2}$ Population less than 15 years of age plus population 60 years or older / population 15-59 years old.

Sources: IMF; United Nations, World Population Prospects. 


\section{Graph A3}

\section{Size of financial market ${ }^{1,2}$}

Broad money ${ }^{3}$
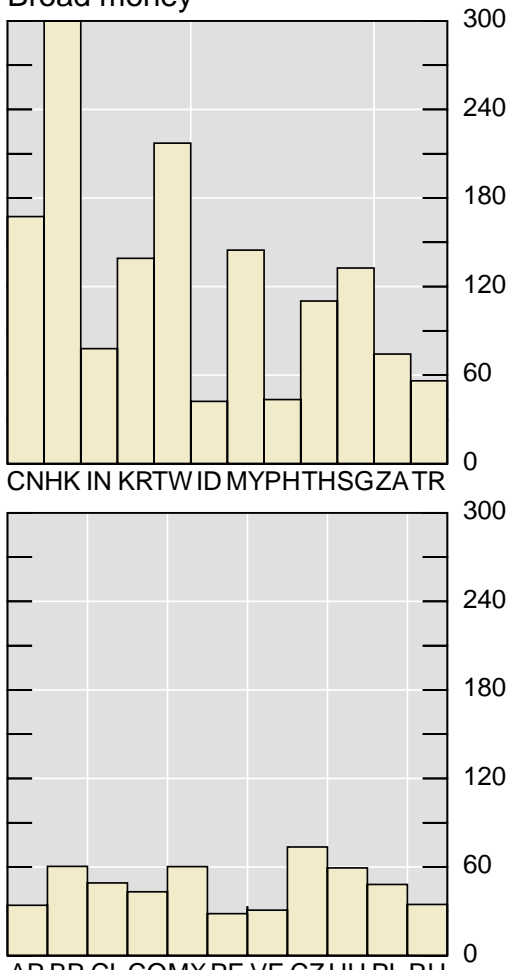

Debt securities

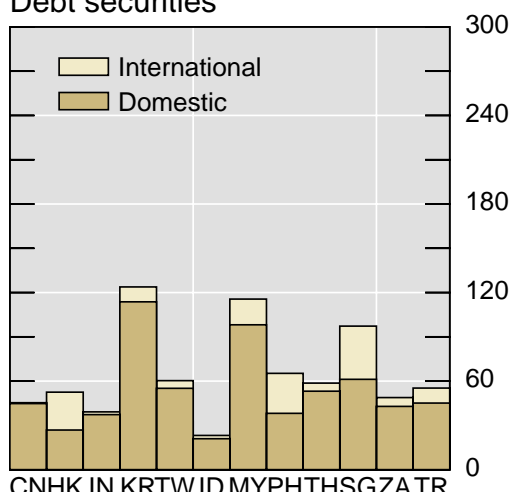

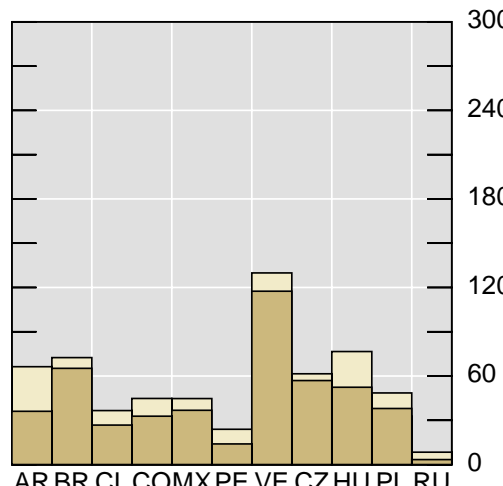

Stock market capitalisation ${ }^{4}$

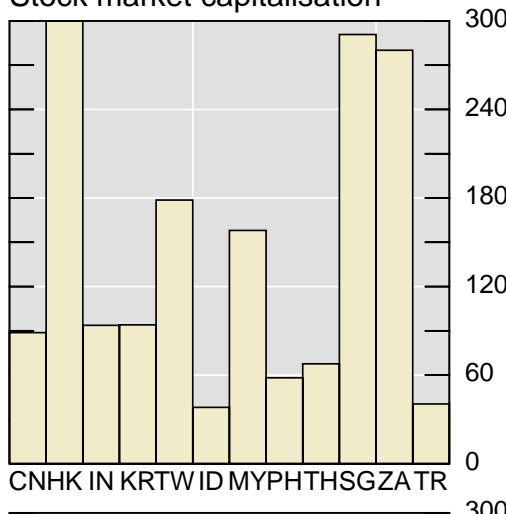

300

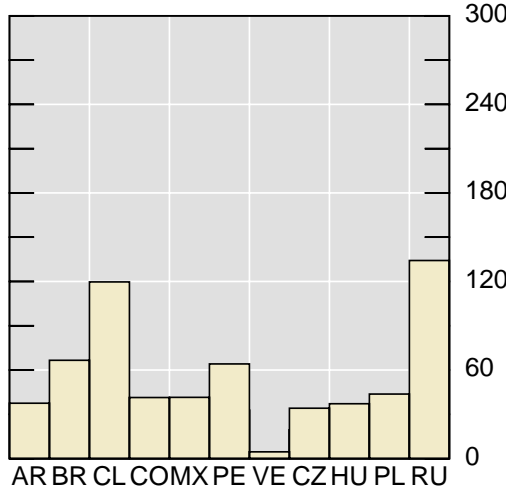

80

20

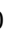

80

20

60

$\mathrm{AR}=$ Argentina; $\mathrm{BR}=$ Brazil; $\mathrm{CL}=$ Chile; $\mathrm{CN}$ = China; $\mathrm{CO}=$ Colombia; $\mathrm{CZ}=$ Czech Republic; $\mathrm{HK}=$ Hong Kong SAR; $\mathrm{HU}=$ Hungary; $I D$ = Indonesia; $I N=$ India; $K R=$ Korea; $M X=$ Mexico; $M Y=$ Malaysia; $P E=$ Peru; $P H=$ Philippines; $P L=$ Poland; $R U$ = Russia; $\mathrm{SG}=$ Singapore; $\mathrm{TH}=$ Thailand; $\mathrm{TR}=$ Turkey; $\mathrm{TW}=$ Taiwan (China); $\mathrm{VE}=$ Venezuela; $\mathrm{ZA}=$ South Africa.

${ }^{1}$ As a percentage of GDP. $\quad{ }^{2}$ End-2006 figures. $\quad{ }^{3} 345 \%$ for Hong Kong SAR. $\quad{ }^{4} 904 \%$ for Hong Kong SAR.

Sources: IMF; Standard \& Poor's; BIS. 


\section{Graph A4}

Size of financial market
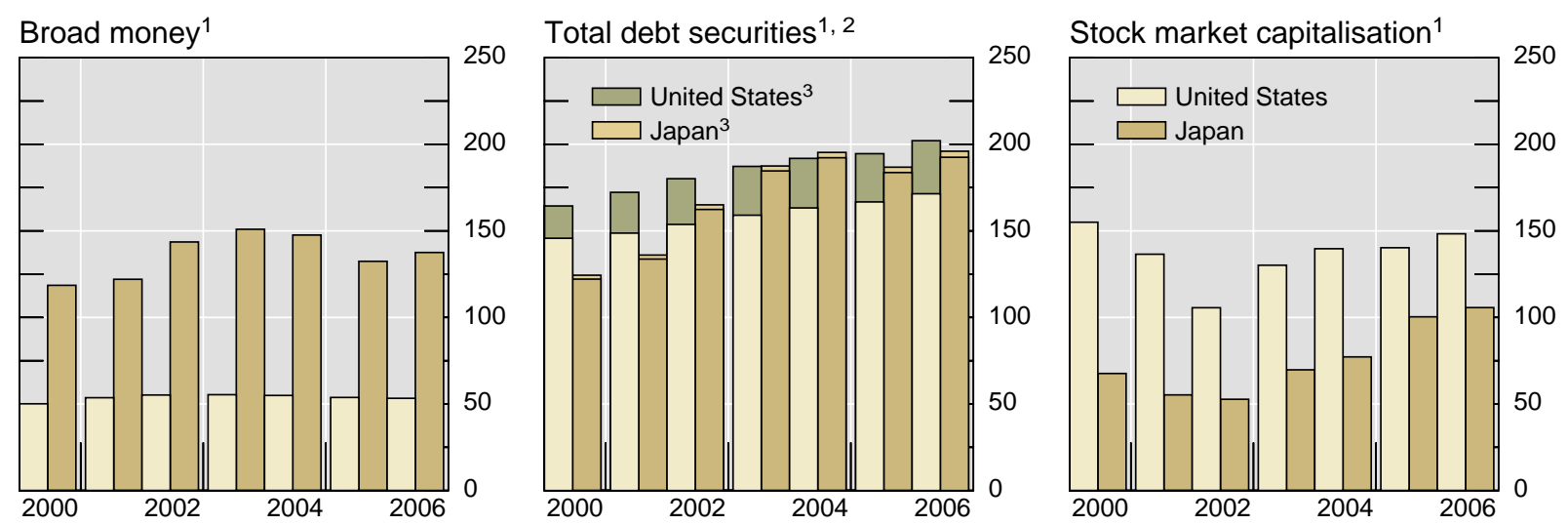

${ }^{1}$ As a percentage of GDP. $\quad{ }^{2}$ Covers domestic and international debt securities. ${ }^{3}$ International.

Sources: IMF; World Federation of Exchanges; BIS.

Graph A5

\section{Liquidity indicator ${ }^{1}$}

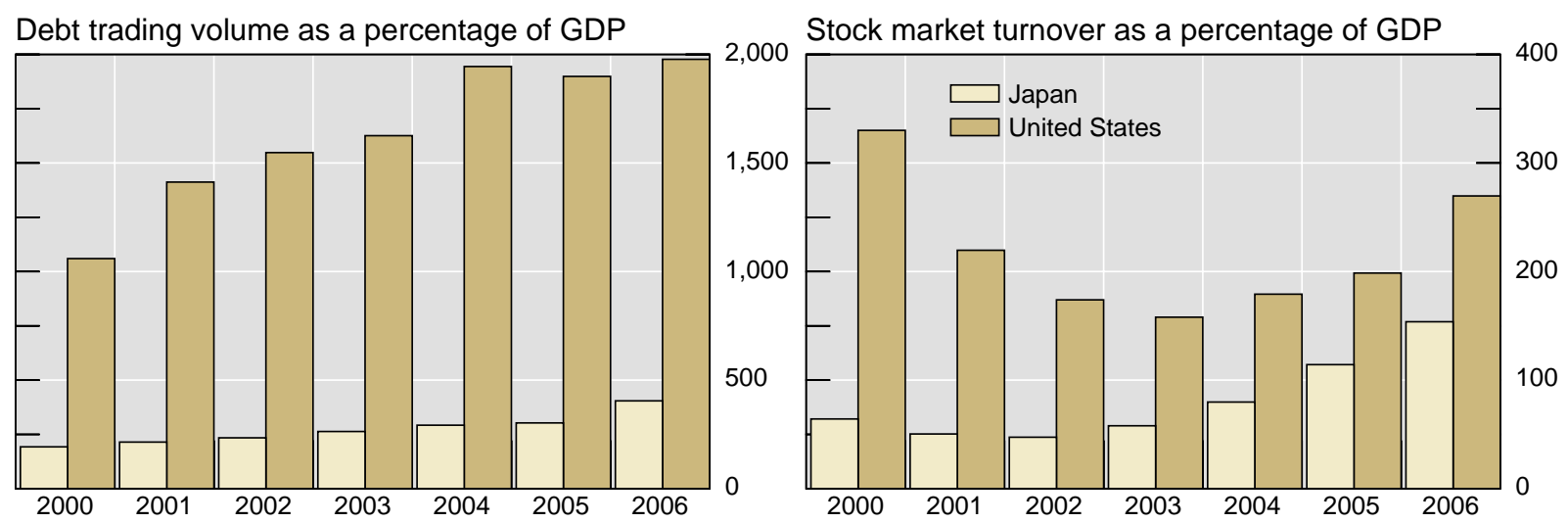

${ }^{1}$ Estimates of the annual value of secondary transactions in equities and bonds.

Source: National data. 


\section{References}

Arenas de Mesa, A, D Bravo, J R Behrman, O S Mitchell and P Todd (2008): "The Chilean pension reform turns 25: lessons from the social protection survey", in S J Kay and T Shinha (eds), Lessons from pension reform in the Americas, Oxford University Press.

Bateman, H (2007): Pension reform and the development of pension systems: an evaluation of World Bank assistance, World Bank.

Batini, N, T Callen and W McKibbin (2006): "The global impact of demographic change", IMF Working Paper WP/06/9, January.

Beshears, J, J J Choi, D Laibson and B C Madrian (2008). "The importance of default options for retirement saving outcomes: evidence from the USA", in S J Kay and T Shinha (eds), Lessons from pension reform in the Americas, Oxford University Press.

Berstein, S and R Chumacero (2005): "Cuantificación de los costos de los límites de inversión para los fondos de pensiones chilenos", Documento de Trabajo no 3, Superintendencia de Administradoras de Fondos de Pensiones, April.

Bloom D E and J G Williamson (1998): "Demographic transitions and economic miracles in East Asia", World Bank Economic Review, vol 12, no 3, pp 419-55.

Buliř, A and A Swiston (2006): "What explains private saving in Mexico?", IMF Working Paper WP/06/191, August.

Carranza, E and E Morón (2008): “The Peruvian pension reform: ailing or failing?", in S J Kay and T Shinha (eds), Lessons from pension reform in the Americas, Oxford University Press.

Chan, L, J A Santaella and J E Suh (2006): How does developing domestic financial markets affect asset allocation in emerging market economies, www.bis.org/publ/wgpapers/cgfs27chan.pdf.

Chinn, $\mathrm{M}$ and $\mathrm{H}$ Ito (2007): "East Asia and global imbalances: saving, investment, and financial development", NBER Working Paper, no 13364, September.

Cogley, T (1998): "The baby boom, the baby bust, and asset markets", FRBSF Economic Letters, 98-20, 26 June, www.frbsf.org/econrsrch/wklyltr/wklyltr98/el98-20.html.

Committee on the Global Financial System (2007): "Institutional investors, global savings and asset allocation", CGFS Publications, no 27, February.

Cowan, K, D Rappoport and J Selaive (2008): "Tipo de cambio y límites de inversión en el extranjero de los fondos de pensiones", in Central Bank of Chile, Informe de Estabilidad Financiera, Segundo Semestre 2007.

Davis, E P (2005): "The role of pension funds as institutional investors in emerging markets", paper presented at the Korean Development Institute Conference, Seoul, March.

Desormeaux J, J, K Fernández D and P García S (2008): "Financial implications of capital outflows in Chile: 1998-2008", this volume.

Dunaway, S and V Arora (2007): "Pension reform in China: the need for a new approach", IMF Working Paper WP/07/109.

Espinosa-Vega, M A and T Sinha (2000): "A primer and assessment of social security reform in Mexico", Federal Reserve Bank of Atlanta Economic Review, first quarter, pp 1-23, available at www.frbatlanta.org/filelegacydocs/Espinosa-Sinha.pdf.

Gollier, C (2005): "Optimal portfolio management for individual pension plans", manuscript, University of Toulouse (GREMAQ, IDEI), 7 November.

Gudmundsson, M (2001): "The Icelandic pension system”, Central Bank of Iceland Monetary Bulletin, 2001/1. 
Holzmann, R, R Palacios and A Zviniene (2004): "Implicit pension debt: issues, measurement and scope in international perspective", World Bank Discussion Papers, no 403.

HSBC Global Research (2006): "Asia invests more in itself”, Global Insights, May.

James, E (2004): "Reforming social security: what can Indonesia learn from other countries?", paper prepared for USAID conference, June.

James, E, J Smalhout and D Vittas (2001): "Administrative costs and the organization of individual account systems: a comparative perspective", in R Holzmann and J Stiglitz (eds), New ideas about old age security, World Bank. Revised version published in: OECD, Private pensions systems: administrative costs and reforms, 2001.

Kay, S J and T Sinha (2008): Lessons from pension reform in the Americas, Oxford University Press.

Kotlikoff L (2006): "Pensions reform - the triumph of form over substance?", lecture presented to the Latin American meeting of the Econometric Society and the annual meeting of Latin American and Caribbean Economic Association, Mexico City, 2 November.

Lee, R (2003): "The demographic transition: three centuries of fundamental change", Journal of Economic Perspectives, Vol 17, number 4, Fall.

Lee, R and A Mason (2007): "Age, aging and economic growth", paper presented at a workshop on Population Aging and Economic Growth, Cambridge MA, 18-19 May.

Levine, R (2004): "Finance and growth: theory and evidence", NBER Working Papers, no 10766, September.

Loayza, N, K Schmidt-Hebbel and L Servén (2000): "What drives private saving across the world?", Review of Economics and Statistics, vol 82, May, pp165-81.

Matijascic, M and S J Kay (2008): "Pensions in Brazil: reaching the limits of parametric reforms in Latin America", in S J Kay and T Shinha (eds), Lessons from pension reform in the Americas, Oxford University Press.

Mohan, R (2007): "Capital account liberalisation and conduct of monetary policy - the Indian experience", paper presented at an International Monetary Seminar on Globalisation, Inflation and Financial Markets, organised by the Bank of France, Paris, 14 June.

Mohanty, M and P Turner (2008): "Transmission mechanisms for monetary policy in emerging market economies: what is new?", in BIS Papers, no 35.

Moon, H (2002): "The Korean pension system: current state and tasks ahead", paper presented at the OECD/INPRS/KOREA Conference on Private Pensions in Asia, Seoul, 24-25 October.

Moreno, R (2006): "The changing nature of risks facing banks", in BIS Papers, no 28, August.

__ (2007): "Experiences with current account deficits in Southeast Asia," Central Bank of Chile Working Papers, no 452, December.

OECD (2007): Survey of investment regulations of pension funds, July.

Poirson, H K (2007): "Financial market implications of India's pension reform”, IMF Working Paper WP/07/85, April.

Reyes, G (2006): "Development of pension reform in Chile", presentation in Poland.

Roldos, J (2007): "Pension reform and macroeconomic stability in Latin America", IMF Working Paper WP/07/108. 
Vargas, H and C Varela (2008): "Capital flows and financial assets in Colombia: recent behavior, consequences and challenges for the central bank", this volume.

Walker, E and F Lefort (2002): "Pension reform and capital markets: are there any (hard) links?", Social Protection Discussion Paper Series, no 0201. 